\title{
Morpho-physiological responses of a subtropical strain of Cylindrospermopsis raciborskii (Cyanobacteria) to different light intensities
}

\author{
Juliana Wojciechowski*, Luciano Felício Fernandes' and Fernanda Vitória Buck Fonseca'
}

Received: December 8, 2015

Accepted: March 21, 2016

\begin{abstract}
The toxigenic cyanobacterium Cylindrospermopsis raciborskii previously restricted to tropical latitudes, has been increasingly reported in temperate lakes in recent decades. The causes of its biogeographical expansion are under investigation, but efficient physiological adaptation to changes in temperature and light regimes are likely to be involved. The present study evaluated the morpho-physiological responses of a strain of $C$. raciborskii from southern Brazil to nine light intensities, from 9 to $250 \mu \mathrm{mol}$ photons $\mathrm{m}^{-2} \mathrm{~s}^{-1}$. Blooms of this cyanobacterium are regularly recorded in the region. Morpho-physiological responses were measured based on growth rate and trichome length.

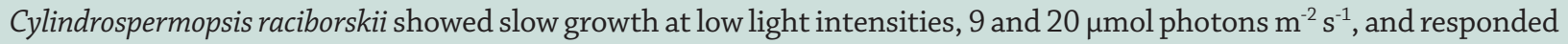
morphologically by increasing the length of trichomes. In turn, the strain displayed constant maximum growth rates at light intensities higher than $50 \mu \mathrm{mol}$ photons $\mathrm{m}^{-2} \mathrm{~s}^{-1}$. These results support the hypothesis that $C$. raciborskii can survive under low light conditions and continue to produce viable trichomes. Moreover, the strain achieved high growth rates under a relatively wide range of light intensities, a physiological adaptation that can potentially be a competitive advantage in the phytoplankton community.
\end{abstract}

Keywords: Cylindrospermopsis, cyanobacteria blooms, experiments, light intensities, morpho-physiological responses, southern Brazil, Subtropical

\section{Introduction}

Cylindrospermopsis raciborskii is a toxigenic cyanobacterium initially ascribed as a tropical to subtropical species (Padisák 1997). However, blooms of this species have increased over the past two decades in many lakes and reservoirs around the world, including temperate latitudes, leading researchers to reclassify the species as cosmopolite (Briand et al. 2004). The increasing number of reports of C. raciborskii and its expanding geographical range has been correlated to the global climatic change and to the eutrophication induced by human activities (O'Neil et al. 2012; Sinha et al. 2012).

There is no unanimity regarding the main environmental mechanisms that have permitted the expansion of $C$. raciborskii into temperate regions. However, achievements have been done to understand the factors that promote the success of this algae worldwide (Piccini et al. 2011; Bonilla et al. 2012).

Among them, wide ranges of environmental preferences and tolerance to variable light intensity have been referred to as factors that promote the expansion of $C$. raciborskii (Briand et al. 2004; Piccini et al. 2011).

\footnotetext{
${ }^{1}$ Setor de Ciências Biológicas, Universidade Federal do Paraná, PO Box 19031, Curitiba, PR, Brazil

* Corresponding author: julianawoj@gmail.com
} 
Light is a significant factor regulating the growth and bloom development of $C$. raciborskii as this species apparently has a peculiar response regarding this abiotic parameter. Historically, Padisák \& Reynolds (1998) considered C. raciborskii a cyanobacterium adapted to grow under low light intensities. Later, more research in the field and using strains from different water bodies has pointed out C. raciborskii grows in a wide range of light intensity (Saker et al. 1999; O'brien et al. 2009; Bittencourt-Oliveira et al. 2011; Pierangelini et al. 2014), while the light requirements for growth were low ( $\mathrm{I}_{\mathrm{k}}$ near to $20 \mu \mathrm{mol}$ photons $\mathrm{m}^{-2} \mathrm{~s}^{-1}$; Briand et al. 2004; Wu et al. 2009; Bonilla et al. 2012; Gomes et al. 2013). These results indicate that $C$. raciborskii is tolerant to a variety of light conditions and, together with its eurithermy, are the main promoters of the current expansion of this cyanobacterium to temperate latitudes.

Several authors have been investigating the effects of light in the ecophysiology of $C$. raciborskii (e.g. Dyble et al. 2006; Carneiro et al. 2009; Mehnert et al. 2010; Marinho et al. 2013); however, many aspects of this interaction have yet to be further elucidated. For instance, few investigations explored the isolated effects of light on the growth of strains from different latitudes, especially in subtropical and tropical environments (Briand et al. 2004; Dyble et al. 2006; Carneiro et al. 2009; Piccini et al. 2011; Bonilla et al. 2012). This cyanobacterium is widespread in Brazilian freshwaters (Bouvy et al. 2000; Sant'Anna \& Azevedo 2000; Tonetta et al. 2015). However, only a few Brazilian strains from Pernambuco state (Briand et al. 2004; Marinho et al. 2013), São Paulo (Carneiro et al. 2009) and Minas Gerais (Marinho et al. 2013) were used for light experiments.

Here, we aimed to investigate the morpho-physiological responses of $C$. raciborskii to different levels of light intensity, after cultivating a strain isolated from a subtropical reservoir used for water supply. We hypothesized that; first, high light intensities could enhance the potential growth of $C$. raciborskii and; second, $C$. raciborskii net growth could be sustained even under low light conditions.

\section{Materials and Methods}

\section{Environmental settings}

The Alagados reservoir ( $25^{\circ} 01^{\prime} 09^{\prime \prime} \mathrm{S}$ and $\left.50^{\circ} 03^{\prime} 43^{\prime \prime} \mathrm{W}\right)$, located in the Paraná state, South Brazil, is used for public water supply and hydroelectric power generation. This reservoir is classified as eutrophic to hypereutrophic (IAP 2004; 2009), with 8.1 meters average depth and area of 7.2 $\mathrm{km}^{2}$ (Rodrigues et al. 2005). Its lentic region is polymictic, with water temperature varying from $12^{\circ} \mathrm{C}$ to $27^{\circ} \mathrm{C}$ (IAP 2009). $Z_{\text {eu }} / Z_{\text {mix }}$ is less than 1 in most of the year (on average 0.7 ), thus, the Alagados reservoir can be considered a turbid environment. Seasonal blooms of Cylindrospermopsis raciborskii (Woloszynska) Seenayya et Subba Raju have regularly been recorded since 2001 (IAP 2009), following a characteristic pattern; increased cell division in late spring, reaching the highest cell densities from January to May. Such a trend coincides with the seasonality of light intensity (and temperature) in South Brazil (Fernandes et al. 2005a). Regular monitoring since 2001 carried out by the state Water Treatment Company (SANEPAR) recorded

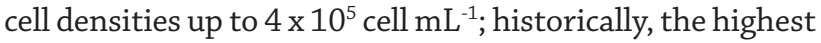
abundance reached $4.25 \times 10^{6} \mathrm{cell} \mathrm{mL}^{-1}$ in August 2006 (IAP 2009). Saxitoxins are commonly recorded in the reservoir associated with $C$. raciborskii blooms. Normally, toxin levels range from $14 \mu \mathrm{g} \mathrm{L}^{-1}$ down to undetectable; a maximum of $644.9 \mu \mathrm{g} \mathrm{L}^{-1}$ was reported in July 2002 (Fernandes et al. 2005b). High cell abundances and presence of saxitoxins were already responsible for sporadic interruptions of supplying drinking water in the region.

During winter, average incident daily solar radiation in the region is around $900 \mathrm{~W} \mathrm{~m}^{-2}$, comparatively lower than the maximum daily solar radiation during summer (1300 $\mathrm{W} \mathrm{m}^{-2}$ ). Day lengths of 11-12 hours in winter are shorter than in summer days, when longer days range from 13 to 14 hours.

\section{Sampling, isolation and culture conditions}

The strain of $C$. raciborskii was isolated from samples obtained with a plankton net $20 \mu \mathrm{m}$ mesh aperture, during a bloom in the Alagados reservoir in May 2011. Pre-monocultures of $C$. raciborskii were kept with ASM-1 medium (Gorham et al. 1964), but modified to use reservoir local water instead distilled water and $\mathrm{pH}$ adjusted from 7.07.5 to 7.8 . Pre-cultures were kept in incubators under 100 $\mu \mathrm{mol}$ photons $\mathrm{m}^{-2} \mathrm{~s}^{-1}$ light provided by daylight fluorescent bulbs (GE 20 Watts) at $20 \pm 1^{\circ} \mathrm{C}$, with $12: 12$ hours light:dark photoperiod.

\section{Experimental design}

Prior to the experiment, two methodologies for monitoring the cell growth were tested: cell abundance $\left(\right.$ cell $\mathrm{mL}^{-1}$ ), estimated from counting in inverted microscope, and optical density (OD) at $750 \mathrm{~nm}$ absorbance through readings in spectrophotometer. As cell abundance was strongly correlated with optical density $(r=0.929, n=22$, $P<0.01$ ), we performed our experiments employing the latter method for practical reasons.

Inoculates of the pre-culture previously acclimated (one life cycle, 10 days) in each light intensity were used to set up cultures in $300 \mathrm{~mL}$ Erlenmeyer flasks filled with $200 \mathrm{~mL}$ of ASM-1 medium. Cell abundance in each initial inoculate was about $2 \times 10^{6}$ cell $\mathrm{mL}^{-1}$, collected from the pre-cultures in exponential growth phase. To investigate the effects of light in the growth of $C$. raciborskii, nine light intensities $(9,20,50,80,100,125,150,200$ and $250 \mu$ mol photons $\left.\mathrm{m}^{-2} \mathrm{~s}^{-1}\right)$ were tested at $25^{\circ} \mathrm{C}$ and $12: 12 \mathrm{~h}$ light:dark cycle, 
manually shaken every day. Proper illumination was ensured by placing the flasks at specific distances from the light source and by using neutral screening. Light intensities were measured with a LI-COR model LI-193 underwater spherical quantum sensor immersed in distilled water. Experiment was carried out in triplicates. Samples were taken under sterile conditions from each of the treatments every 24 hours at the same hour over 20 days. Optical density at 750 $\mathrm{nm}$ absorbance of each of the samples was measured with a Hitachi U-2910 spectrophotometer. Cell abundances (cell $\left.\mathrm{mL}^{-1}\right)$ for three treatments $(9,100$ and $250 \mu \mathrm{mol}$ photons $\mathrm{m}^{-2} \mathrm{~s}^{-1}$ ) were estimated from counting trichomes and cells in Sedgewick-Rafter chambers. A minimum number of 1000 trichomes were counted. Fifty trichomes of each treatment were measured in inverted microscope (Olympus IX70, equipped with phase contrast) at 2-days intervals ( $n$ $=5400$ trichomes).

\section{Estimation of growth and statistics}

Growth rate $\left(\mu\right.$ day $\left.^{-1}\right)$ of each treatment was calculated daily, after Andersen (2005). Maximum growth rate $\mu_{\max }$, initial slope of the light vs. growth rate relationship $(\alpha)$, and the light intensity approaching the growth saturation $I_{\mathrm{k}}\left(I_{\mathrm{k}}\right.$ $\left.=\mu_{\max } \alpha^{-1}\right)$ were obtained from the adjusted model of Jassby \& Platt (1976). One-way analysis of variance (ANOVA) was performed to verify significant differences between the average growth rates in replicates cultures incubated at different light intensities, as well as differences between trichome lengths in the three specific light intensities selected. A Tukey HSD multiple comparison analysis was made a posteriori to discriminate the treatments showing significant differences $(P<0.05)$. Analyses were performed in R software 3.1.3 (R Core Team 2015) using package stats (Chambers et al. 1992).

\section{Results}

\section{Growth under different light intensities}

Growth of $C$. raciborskii strain was influenced by light intensity $\left(\mathrm{F}_{8.171}=5.71, P=0.02\right)$, although two main distinct trends in the curves were recorded: slower growth at 9 and 20 $\mu \mathrm{mol}$ photons $\mathrm{m}^{-2} \mathrm{~s}^{-1}$, and faster ones at $50 \mu \mathrm{mol}$ photons $\mathrm{m}^{-2}$ $\mathrm{s}^{-1}$ and above (Fig. 1). Net increase of trichomes was minimal in cultures grown at $9 \mu \mathrm{mol}$ photons $\mathrm{m}^{-2} \mathrm{~s}^{-1}$. Maximum optical density (OD) reached only 0.013 after 20 days of culturing. (Fig. 1). We found significant differences $\left(\mathrm{F}_{8.171}=\right.$ $5.71, P=0.02$ ) between the growth averages (based on OD at $750 \mathrm{~nm}$ ) of the strain tested at different light intensities. Significant differences $(P<0.05)$ were found between the two lower light treatments ( 9 and $20 \mu$ mol photons $\mathrm{m}^{-2} \mathrm{~s}^{-1}$ ) and cultures growing at higher light intensities. Further, there were significant differences between $9 \mu$ mol photons

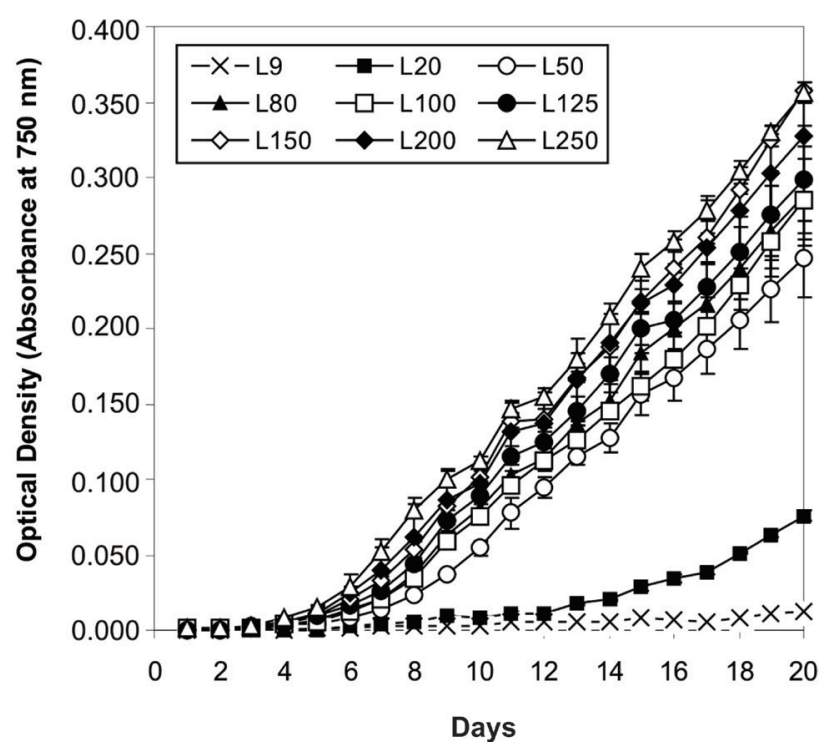

Figure 1. Growth curves of $C$. raciborskii strain from Alagados reservoir at nine different light intensities, based on readings at optical density of $750 \mathrm{~nm}$. Vertical bars indicate the range of values for three replicates. Codes are as follows: L9 = light intensity at 9 $\mu \mathrm{mol}$ photons $\mathrm{m}^{-2} \mathrm{~s}^{-1}$ and so on.

$\mathrm{m}^{-2} \mathrm{~s}^{-1}$ treatment and light intensities above $80 \mu \mathrm{mol}$ photons $\mathrm{m}^{-2} \mathrm{~s}^{-1}\left(100,125,150,200\right.$ and $250 \mu \mathrm{mol}$ photons $\left.\mathrm{m}^{-2} \mathrm{~s}^{-1}\right)$. Regarding cultures at $20 \mu \mathrm{mol}$ photons $\mathrm{m}^{-2} \mathrm{~s}^{-1}$, differences occurred for intensities higher than $125 \mu \mathrm{mol}$ photons $\mathrm{m}^{-2}$ $\mathrm{s}^{-1}\left(150,200\right.$ and $250 \mu \mathrm{mol}$ photons $\left.\mathrm{m}^{-2} \mathrm{~s}^{-1}\right)$.

Cultures grown at light intensities higher than $50 \mu \mathrm{mol}$ photons $\mathrm{m}^{-2} \mathrm{~s}^{-1}$ reached optical densities as high as 0.250 and 0.350; at least 20 times higher than observed for 9 and $20 \mu \mathrm{mol}$ photons $\mathrm{m}^{-2} \mathrm{~s}^{-1}$ treatments (Fig. 1). These cultures entered the log-growth phase at the third or fourth day incubation except the culture at $125 \mu \mathrm{mol}$ photons $\mathrm{m}^{-2} \mathrm{~s}^{-1}$, which started the log growth earlier in the second day. Log phase lasted 8 to 10 days in all the treatments ranging from 50 and $250 \mu \mathrm{mol}$ photons $\mathrm{m}^{-2} \mathrm{~s}^{-1}$. There were no significant differences in growth among the cultures submitted to higher light intensities (50 - $250 \mu \mathrm{mol}$ photons $\mathrm{m}^{-2} \mathrm{~s}^{-1}$ ).

Growth rates $\left(\mu\right.$ day $\left.^{-1}\right)$ of cultures growing at 9 and 20 $\mu \mathrm{mol}$ photons $\mathrm{m}^{-2} \mathrm{~s}^{-1}$ were $0.14 \pm 0.01$ and $0.24 \pm 0.01$ day $^{-1}$, respectively (Fig. 2). On the other hand, maximum rates were achieved in cultures incubated at and higher than 50 $\mu \mathrm{mol}$ photons $\mathrm{m}^{-2} \mathrm{~s}^{-1}$, from 0.26 to 0.30 day $^{-1}$. The value of $I_{\mathrm{k}}$ calculated for the $C$. raciborskii strain was around 19 $\mu \mathrm{mol}$ photons $\mathrm{m}^{-2} \mathrm{~s}^{-1}$ and the slope was $0.0361 \mathrm{~d}^{-1} \mu \mathrm{mol}$ photons $\mathrm{m}^{-2} \mathrm{~s}^{-1}$.

\section{Morphology of trichomes}

Average length of trichomes in cultures grown at 9 $\mu \mathrm{mol}$ photons $\mathrm{m}^{-2} \mathrm{~s}^{-1}$ was significantly larger than in the treatments at 100 and $250 \mu \mathrm{mol}$ photons $\mathrm{m}^{-2} \mathrm{~s}^{-1}\left(\mathrm{~F}_{2.24}=\right.$ 13.103, $P<0.001)$ (Fig. 3). At low light intensity $(9 \mu \mathrm{mol}$ 
photons $\mathrm{m}^{-2} \mathrm{~s}^{-1}$ ) trichomes were longer, ranging from 313 to $790 \mu \mathrm{m}$ length, while cultures at higher light presented shorter trichomes, 80 to $320 \mu \mathrm{m}$. In all three treatments monitored, trichomes remained straight throughout the experiment.

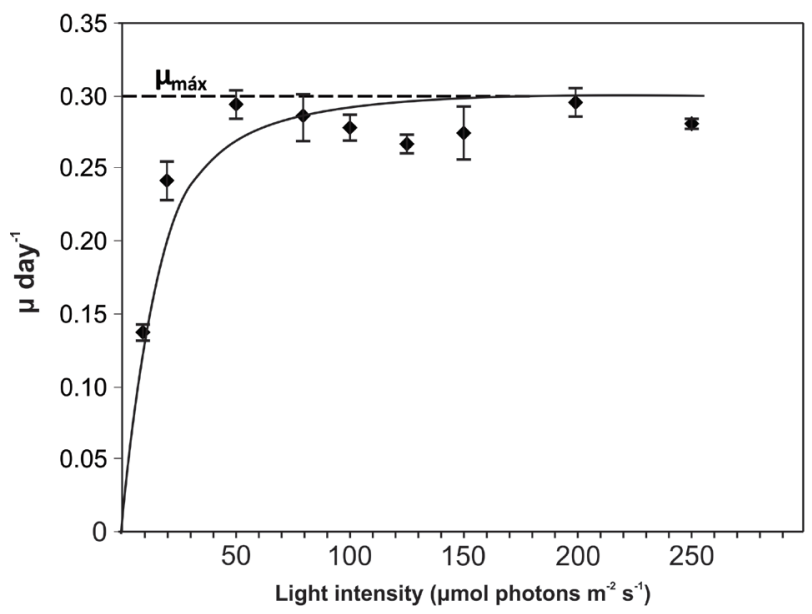

Figure 2. Growth rates $\left(\mu\right.$ day $\left.^{-1}\right)$ of $C$. raciborskii isolated from Alagados reservoir at different light intensities, with the indication of $\mu_{\max }\left(0.3 \mu\right.$ day $\left.^{-1}\right)$. Vertical bars indicate the range of values for three replicates.

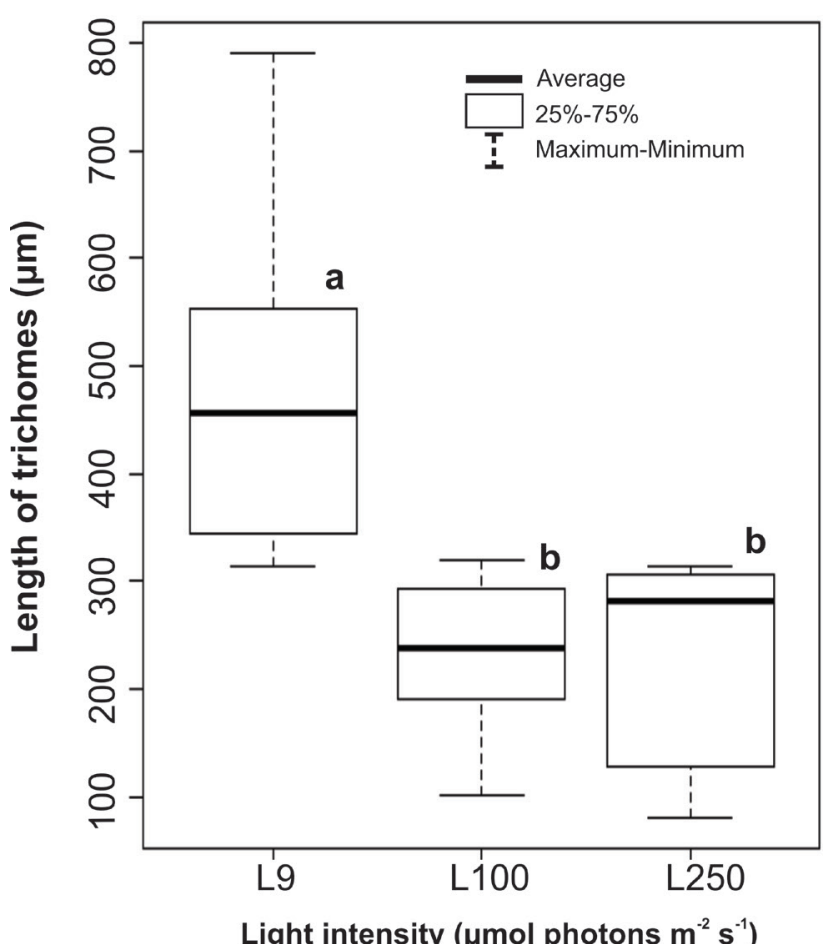

Figure 3. Length of trichomes $(\mu \mathrm{m})$ in three light treatments, incubated at 9 (L9), 100 (L100) and $250 \mu \mathrm{mol}$ photons $\mathrm{m}^{-2} \mathrm{~s}^{-1}$ (L250). Letters $\mathbf{a}$ and $\mathbf{b}$ indicate significant statistical differences between treatments $(P<0.005)$.

\section{Discussion}

\section{Growth responses}

In this experiment, increasing light intensities promoted the growth enhancing of the $C$. raciborskii strain isolated from the Alagados reservoir. The growth rate doubled when the strain was cultivated at $50 \mu \mathrm{mol}$ photons $\mathrm{m}^{-2} \mathrm{~s}^{-1}$ or higher compared to $9 \mu \mathrm{mol}$ photons $\mathrm{m}^{-2} \mathrm{~s}^{-1}$. Moreover, the strain attained maximum growth over a wide range of light intensity $\left(50-250 \mu \mathrm{mol}\right.$ photons $\left.\mathrm{m}^{-2} \mathrm{~s}^{-1}\right)$. This finding differs from other results, which reported a more narrow range of optimum light ( 75 to $125 \mu \mathrm{mol}$ photons $\mathrm{m}^{-2} \mathrm{~s}^{-1}$ ) for strains isolated from a variety of sites (Dyble et al. 2006; Bonilla et al. 2012; Briand et al. 2004). The ability of C. raciborskii to grow faster than other diazotrophic species under high light intensities is an important physiological feature (Fabbro \& Duivenvoorden 1996; Briand et al. 2004) that enhances their potential threat for water use, particularly in tropical regions.

During our experiment, the $C$. raciborskii strain showed no evidence of photoinhibition when submitted to light levels as high as $250 \mu \mathrm{mol}$ photons $\mathrm{m}^{-2} \mathrm{~s}^{-1}$, considering that maximum optical density and pattern of growth curves were statistically similar to the treatments at 50 to $200 \mu \mathrm{mol}$ photons $\mathrm{m}^{-2} \mathrm{~s}^{-1}$. Indeed, strains from different latitudes are capable of fast growth rate ( $>0.5 \mathrm{day}^{-1}$ ) under light levels as high as $500 \mu \mathrm{mol}$ photons $\mathrm{m}^{-2} \mathrm{~s}^{-1}$ in laboratory (Briand et al. 2004). It might be that $C$. raciborskii is adapted to grow (up to bloom densities) at even higher irradiances in natural conditions than those tested in laboratory, especially in tropical regions subjected to year-round high solar irradiances (e.g. Dokulil \& Mayer 1996; Fabbro \& Duivenvoorden 1996). Therefore, our data corroborate previous laboratory evidence suggesting that $C$. raciborskii is able to explore a wide range of light intensities, spanning from 20 to $500 \mu \mathrm{mol}$ photons $\mathrm{m}^{-2} \mathrm{~s}^{-1}$ at least (Bouvy et al. 1999; 2000; Briand et al. 2004; our results).

Cultures incubated at low light intensities (9 and 20 $\mu \mathrm{mol}$ photons $\mathrm{m}^{-2} \mathrm{~s}^{-1}$ ) were unable to attain intensive cell division, showing significantly lower growth rate (0.14 and 0.24 day $^{-1}$, respectively) when compared to the other higher light treatments tested. Nevertheless, the strain sustained net increase even under low light conditions, with potential implications to the success of $C$. raciborskii. This is particularly relevant in Alagados reservoir, where light is a regulating factor of phytoplankton growth during late fall and winter, due to both the seasonal declining of atmospheric irradiance coupled with shortening of day length in fall and winter in South Brazil (Fernandes et al. 2005a), and the mixing zone usually greater than the photic zone (unpublished data). Large overwintering populations are one reason why cyanobacteria with low specific growth rates become dominant in summer 
phytoplankton communities (Reynolds 1994). As reported by Dokulil (2015), the C. raciborskii population of Lake Alte Donau survived adverse periods, being able to inoculate the phytoplankton assemblage in the following spring. The same was reported by other authors in other regions of the globe (Everson et al. 2011; Wood et al. 2014), including the temperate zone, which most authors suggest that the species survive in winter in the form of akinetes (Mehnert et al. 2010).

The light saturation parameter $\left(I_{k}\right)$ is a reliable indicator to evaluate light requirements of a certain species and to allow for comparisons between species (Briand et al. 2004). The calculated $I_{\mathrm{k}}$ for the strain tested here is $19 \mu \mathrm{mol}$ photons $\mathrm{m}^{-2} \mathrm{~s}^{-1}(\alpha=0.0361)$, which is similar to most other values for C. raciborskii from different regions of the world, ranging from 15 to $26 \mu \mathrm{mol}$ photons $\mathrm{m}^{-2} \mathrm{~s}^{-1}$ (Shafik et al. 2001; Briand et al. 2004; Dyble et al. 2006). Briand et al. (2004) included four tropical strains (two from Brazil), but no correlationship was found between latitude and $I_{\mathrm{k}}$, suggesting there is no separation among the clones tested. Recently, Bonilla et al. (2012) recorded $I_{\mathrm{k}}$ as low as $8 \mu \mathrm{mol}$ photons $\mathrm{m}^{-2} \mathrm{~s}^{-1}$ for Uruguayan strains isolated from shallow lakes. In our case, the strain can be considered highly adapted to low light due to its low $I_{\mathrm{k}}$ and adequate growth rates $\left(\mu_{\max }=\right.$ 0.26 at $50 \mu \mathrm{mol}$ photons $\mathrm{m}^{-2} \mathrm{~s}^{-1}$ ), being potentially able to saturate photosynthesis even at low irradiances in the field. Among diazotrophic genera, relatively low $I_{\mathrm{k}}$ are commonly found in bloom-forming species adapted to low luminosity like Planktothrix agardhii, Planktothrix rubescens and Limnothrix redekei (Padisák \& Reynolds 1998; Reynolds et al. 2002; Bonilla et al. 2012). These physiological traits led Reynolds et al. (2002) to classify those cyanobacteria and C. raciborskii in the functional groups $\mathrm{S}$ and $\mathrm{R}$ (tolerant to low light conditions). The capacity of undergoing growth at low irradiance also enables $C$. raciborskii to thrive under the light limiting conditions imposed by periods of intensive phytoplankton growth (Padisák 1997; Padisák \& Reynolds 1998; Briand et al. 2002; Havens et al. 2003). The few previous investigations in Brazil recording light intensity in the field found elevated abundances of $C$. raciborskii at irradiances as low as $15 \mu \mathrm{mol}$ photons $\mathrm{m}^{-2} \mathrm{~s}^{-1}$ (Bouvy et al. 1999; 2000) in shallow eutrophic lakes. Tolerance to shading, usually prevalent in turbid environments, adds to the factors invoked to explain the dominance of C. raciborskii in Brazilian lakes. Therefore, in polimyctic reservoirs with active vertical mixing like Alagados and the ability of sustaining growth under variable light confers a relevant ecological advantage to $C$. raciborskii, particularly since this species can compensate lower light availability by saturating its photosynthetic rate.

\section{Morphological responses}

The C. raciborskii strain also showed an interesting morphological response to the different light regimes tested in this work. Significant increase in length, up to $790 \mu \mathrm{m}$, was observed in trichomes incubated at low light intensity ( 9 $\mu \mathrm{mol}$ photons $\mathrm{m}^{-2} \mathrm{~s}^{-1}$ ) in comparison to the shorter trichome length achieved at higher intensities.

The relevance of investigating the morphology of trichomes and cells of cyanobacteria are two-fold. First, information about length, width, presence or absence of heterocytes and akinetes among others furnishes support to taxonomic studies. Second, alteration in morphology can reflect changing in environmental parameters. Cylindrospermopsis raciborskii has been found highly variable morphologically, making its identification somewhat difficult in some situations (Komárková et al. 1999). Most of the studies investigating the factors responsible for changes in morphology of $C$. raciborskii tested temperature (Chonudomkul et al. 2004) or nutrients (Saker \& Neilan 2001; Shafik et al. 2003). On the other hand, only a few papers aimed to verify the influence of light intensity on trichomes (Bittencourt-Oliveira et al. 2012; Bonilla et al. 2012; Beamud et al. 2016).

It is difficult to discuss the factors underlying the observed changes in C. raciborskii morphology. We preliminarily attribute the enlargement of trichomes in our experiment as an adaptation to optimize light absorption under limiting conditions. However, contrary to our results, Bonilla et al. (2012) observed longer and more voluminous individuals when cultivated at higher light intensities (100 $\mu \mathrm{mol}$ photons $\left.\mathrm{m}^{-2} \mathrm{~s}^{-1}\right)$. In the field, these authors found no correlation between biovolume of $C$. raciborskii and ambient light availability in the water column. Moreover, other authors found a positive relationship between length of trichomes and input of nutrients either in laboratory or environmental conditions, especially phosphorus and nitrogen (Komárková et al. 1999; Saker \& Neilan 2001; Shafik et al. 2003).

\section{Concluding remarks}

Laboratory experiments are one of many important steps to understand the adaptiveness and success of toxigenic species in various freshwater systems across latitudes as well as having specific water circulation patterns and trophic status. We recognize that a number of genetically diverse strains should make up the population of $C$. raciborskii in reservoirs and the response of individual strains to light may be specific. Therefore, the physiological responses of one or two strains from a given reservoir do not necessarily reflect what happens with the population. Nonetheless, our laboratory results suggest that $C$. raciborskii can survive under low light conditions, still producing viable trichomes. Additionally, our results also give additional support to the hypothesis that $C$. raciborskii is a tolerant cyanobacterium adapted to thrive in distinct light conditions irrespective of latitudinal variation (Briand et al. 2004). Hence, the species can dominate the phytoplankton in 
tropical, subtropical or temperate freshwater systems; such a geographic spreading should have also been favored by the observed rising temperatures of lakes around the world in the last three decades (Bonilla et al. 2012). Nonetheless, further investigations using a greater number of strains and from different latitudes are recommended to better elucidate the role of light on the growth, physiology and phenotypic plasticity of $C$. raciborskii. Moreover, laboratory experiments coupled with field studies will allow for a better understanding of the causes underlining the seasonal blooming of this harmful species in subtropical regions.

\section{Acknowledgements}

We acknowledge the financial support provided by PETROBRAS (Petróleo Brasileiro S.A) and SANEPAR (Companhia de Saneamento do Paraná). J. W. benefited from a fellowship granted by CAPES (Coordenação de Aperfeiçoamento de Pessoal de Nível Superior). We thank Dr. André A. Padial for significant assistance in statistics and Dr. Thelma A. Ludwig and Dr. Liliana Rodrigues for valuable improvements to the early versions of the manuscript.

\section{References}

Andersen RA. 2005. Algal Culturing Techniques. Oxford, Elsevier Academic Press.

Beamud G, Vico P, Haakonsson S, et al. 2016. Influence of UV-B radiation on the fitness and toxin expression of the cyanobacterium Cylindrospermopsis raciborskii. Hydrobiologia 763: 161-172.

Bittencourt-Oliveira MC, Moura NA, Hereman TC, Dantas EW. 2011. Increase in Straight and Coiled Cylindrospermopsis raciborskii (Cyanobacteria) Populations under Conditions of Thermal DeStratification in a Shallow Tropical Reservoir. Journal of Water Resource and Protection 3: 245-252.

Bittencourt-Oliveira MC, Buch B, Hereman TC, Arruda-Neto JDT, Moura AN, Zocchi SS. 2012. Effects of light intensity and temperature on Cylindrospermopsis raciborskii (Cyanobacteria) with straight and coiled trichomes: growth rate and morphology. Brazilian Journal of Biology 72: 343-351.

Bonilla S, Aubriot L, Soares MCS, et al. 2012. What drives the distribution of the bloom-forming cyanobacteria Planktothrix agardhii and Cylindrospermopsis raciborskii? FEMS Microbology Ecology 79: 594-607.

Bouvy M, Molica R, Oliveira S, Marinho M, Beker B. 1999. Dynamics of a toxic cyanobacterial bloom (Cylindrospermopsis raciborskii) in a shallow reservoir in the semi-arid region of Northeast, Brazil. Aquatic Microbial Ecology 20: 285-297.

Bouvy M, Falcão D, Marinho M, Pagano M, Moura A. 2000. Occurence of Cylindrospermopsis (Cyanobacteria) in 39 Brazilian tropical reservoirs during the 1998 drought. Aquatic Microbial Ecology 15: 122-164.

Briand JF, Robillot C, Quiblier-Llobéras C, Humbertd JF, Couté A, Bernard C. 2002. Environmental context of Cylindrospermopsis raciborskii (Cyanobacteria) blooms in a shallow pond in France. Water Research 36: 3183-3192.

Briand JF, Leboulanger C, Humbert JF, Bernard C, Dufour P. 2004. Cylindrospermopsis raciborskii (Cyanobacteria) invasion at midlatitudes: selection, wide physiological tolerance, or global warming? Journal of Phycology 40: 231-238.

Carneiro RL, Santos MEV, Pacheco ABF, Azevedo SMFO. 2009. Effects of light intensity and light quality on growth and circadian rhythm of saxitoxins production in Cylindrospermopsis raciborskii (Cyanobacteria). Journal of Plankton Research 31: 481-488.
Chambers JM, Freeny A, Heiberger RM. 1992. Analysis of variance; designed experiments. In: Chambers JM, Hastie TJ. (eds.) Statistical Models in S. Boston, Wadsworth \& Brooks/Cole.

Chonudomkul D, Yongmanitchai W, Theeragool G, et al. 2004. Morphology, genetic diversity, temperature tolerance and toxicity of Cylindrospermopsis raciborskii (Nostocales, Cyanobacteria) strains from Thailand and Japan. FEMS Microbiology Ecology 48: 345-355.

Dokulil MT, Mayer J. 1996. Population dynamics and photosynthetic rates of a Cylindrospermopsis-Limnothrix association in a highly eutrophic urban lake, Alte Donau, Vienna. Archiv fuer Hydrobiologie. Supplementband. Algological Studies 83: 179-195.

Dokulil MT. 2015. Vegetative survival of Cylindrospermopsis raciborskii (Cyanobacteria) at low temperature and low light. Hydrobiologia 1-7.

Dyble J, Tester PA, Litaker RW. 2006. Effects of light intensity on cylindrospermopsin production in the cyanobacterial HAB species Cylindrospermopsis raciborskii. African Journal of Marine Science 28: 309-312.

Everson S, Fabbro L, Kinnear S, Wright P. 2011. Extreme differences in akinete, heterocyte and cylindrospermopsin concentrations with depth in a successive bloom involving Aphanizomenon ovalisporum (Forti) and Cylindrospermopsis raciborskii (Woloszynska) Seenaya and Subba Raju. Harmful Algae 10: 265-276.

Fabbro LD, Duivenvoorden LJ. 1996. Profile of a bloom of the cianobactéria Cylindrospermopsis raciborskii (Woloszynska) Seenaya and Subba Raju in the Fitzroy River in tropical central Queensland. Marine and Freshwater Research 47: 685-694.

Fernandes LF, Lagos PED, Wosiack AC, et al. 2005a. Comunidades fitoplanctônicas em ambientes lênticos. In: Andreoli CV, Carneiro C. (eds.) Gestão integrada de mananciais de abastecimento eutrofizados. Curitiba, Sanepar-Finep. p. 305-366.

Fernandes LF, Wosiack AC, Pacheco CV, Domingues L, Lagos PED. 2005b. Cianobactérias e cianotoxinas. In: Andreoli CV, Carneiro C. (eds.) Gestão integrada de mananciais de abastecimento eutrofizados. Curitiba, Sanepar-Finep. p. 369-388.

Gomes AMA, Marinho MM, Azevedo SMFO. 2013. Which factors are related to the success of Cylindrospermopsis raciborskiiin Brazilian Aquatic Systems? In: Ferrão-Filho AS. (ed.) Cyanobacteria: ecology, Toxicology and Management. New York, Nova Science Publishers Inc. p. 73-94.

Gorham PR, Mclachlan JR, Hammer VT, Kim WK. 1964. Isolation and culture of toxic strains of Anabaena flos-aquae (Lyngb.) de Bréd. Verhandlungen des Internationalen Verein Limnologie 15: 796-804.

Havens KE, James RT, East TL, Smith VH. 2003. N:P ratios, light limitation, and cyanobacterial dominance in a subtropical lake impacted by non-point source nutrient pollution. Environmental Pollution 122: 379-390.

IAP - Instituto Ambiental do Paraná. 2004. Monitoramento da qualidade das águas dos reservatórios do Estado do Paraná no período de 1999 a 2004. http://www.iap.pr.gov.br. 22 Apr. 2013.

IAP - Instituto Ambiental do Paraná. 2009. Monitoramento da qualidade das águas dos reservatórios do Estado do Paraná no período de 2005 a 2008. http://www.iap.pr.gov.br. 22 Apr. 2013.

Jassby AD, Platt T. 1976. Mathematical formulation of the relationship between photosynthesis and light for phytoplankton. Limnology and Oceanography 21: 540-547.

Komárková J, Laudares-Silva R, Senna PAC. 1999. Extreme morphology of Cylindrospermopsisraciborskii (Nostocales, Cyanobacteria) in the Lagoa do Peri, a freshwater coastal lagoon, Santa Catarina, Brazil. Archiv fuer Hydrobiologie Supplementband, Algological Studies 94: 207-222.

Marinho MM, Souza MBG, Lürling M. 2013. Light and Phosphate Competition Between Cylindrospermopsis raciborskii and Microcystis aeruginosa is Strain Dependent. Microbial Ecology 66: 479-488.

Mehnert G, Leunert F, Cirés S, et al. 2010. Competitiveness of invasive and native cyanobacteria from temperate freshwaters under various light and temperature conditions. Journal of Plankton Research 32: 1009-1021.

O’brien KR, Burford MA, Brookes JD. 2009. Effects of light history on primary productivity in a phytoplankton community dominated by the toxic cyanobacterium Cylindrospermopsis raciborskii. Freshwater Biology 54: 272-282. 
O'Neil JM, Davis TW, Burford MA, Gobler CJ. 2012. The rise of harmful cyanobacteria blooms: The potential roles of eutrophication and climate change. Harmful Algae. 14: 313-334.

Padisák J. 1997. Cylindrospermopsis raciborskii (Woloszynska) Seenayya et Subba Raju, and expanding, highly adaptative cyanobacterium: worldwide distribution and review of its ecology. Archiv fuer Hydrobiologie 107: 563-593.

Padisák J, Reynolds CS. 1998. Selection of phytoplankton associations in lake Balaton, Hungary, in response to eutrophication and restoration measures, with special reference to the cyanoprokariotes. Hydrobiologia 384: 41-53.

Piccini C, Aubriot L, Fabre A, et al. 2011. Genetic and eco-physiological differences of South American Cylindrospermopsis raciborskii isolates support the hypothesis of multiple ecotypes. Harmful Algae 10: 644-653.

Pierangelini M, Stojkovic S, Orr PT, Beardall J. 2014. Photosynthetic characteristics of two Cylindrospermopsis raciborskii strains differing in their toxicity. Journal of Phycology 50: 292-302.

Reynolds CS. 1994. The long, the short and the stalled: on the attributes of phytoplankton selected by physical mixing in lakes and rivers. Hydrobiologia 289: 9-21.

Reynolds CS, Huszar V, Kruk C, Naselli-Flores L, Melo S. 2002. Towards a functional classification of the freshwater phytoplankton. Journal of Plankton Research 24: 417-428.

Rodrigues L, Thomaz SM, Agostinho AA, Gomes LC. 2005. Biocenoses em reservatórios: padrões espaciais e temporais. São Carlos, RiMa.

Saker ML, Neilan BA, Griffiths DJ. 1999. Two morphological forms of Cylindrospermopsis raciborskii (Cyanobacteria) isolated from Solomon Dam, Palm Island, Queensland. Journal of Phycology 35: 599-606.
Saker ML, Neilan BA. 2001. Varied Diazotrophies, Morphologies and Toxicities of genetically similar isolates of Cylindrospermopsis raciborskii (Nostocales, Cyanophyceae) from Northern Australia. Applied Environmental Microbiology 67: 1839-1845.

Sant'Anna CL, Azevedo MTP. 2000. Contribution to the knowledge of potentially toxic Cyanobacteria from Brazil. Nova Hedwigia 71: 359385.

Shafik HM, Herodek M, Présing M, Vörös L. 2001. Factors effecting growth and cell composition of cyanoprokaryote Cylindrospermopsis raciborskii (Wolsz) Seenayya et Subba Raju. Archiv fuer Hydrobiologie Supplementband. Algological Studies 103: 75-94.

Shafik HM, Vörös L, Spróber P, Présing M, Kovács A. 2003. Some special morphological features of Cylindrospermopsis raciborskii in batch and continuous cultures. Hydrobiologia 506-509: 163-167.

Sinha R, Pearson LA, Davis TW, Burford MA, Orr PT, Neilan BA. 2012. Increased incidence of Cylindrospermopsis raciborskii in temperate zones e is climate change responsible? Water Research 46: 1408-1419.

Tonetta D, Hennemann MC, Brentano DM, Petrucio MM. 2015. Considerations regarding the dominance of Cylindrospermopsis raciborskii under low light availability in a low phosphorus lake. Acta Botanica Brasilica 29: 448-451.

Wood SA, Pochon X, Luttringer-Plu L, Vant BN, Hamilton DP. 2014. Recent invader or indicator of environmental change? A phylogenetic and ecological study of Cylindrospermopsis raciborskii in New Zealand. Harmful Algae 39: 64-74.

Wu Z, Shi J, Li R. 2009. Comparative studies on photosynthesis and phosphate metabolism of Cylindrospermopsis raciborskii with Microcystis aeruginosa and Aphanizomenon flos-aquae. Harmful Algae 8: 910-915. 